\title{
The influence of diatomite on the growth and development of Hordeum sativum on ordinary chernozem polluted with benzo[a]pyrene
}

\author{
Anatoly Barakhov ${ }^{1, *}$, Tatiana Minkina ${ }^{1}$, Tamara Dudnikova ${ }^{1}$, Natalia Chernikova ${ }^{1}$, \\ Viacheslav Lebedenko ${ }^{2}$, Svetlana Ponomareva ${ }^{2}$, Svetlana Shvedova ${ }^{2}$, Dmitry Rudoy ${ }^{2}$, \\ Anastasiya Olshevskaya ${ }^{2}$, and Oleg Polushkin ${ }^{2}$ \\ ${ }^{1}$ Southern Federal University, 194/1, prosp. Stachki, 344090, Rostov-on-Don, Russia \\ ${ }^{2}$ Don State Technical University, 1, sq. Gagarina, 344003, Rostov-on-Don, Russia
}

\begin{abstract}
The effect of various doses of diatomite introduced into soil artificially contaminated by benzo[a]pyrene was analyzed. The negative effect of benzo[a]pyrene on the growth of barley (Hordeum sativum distichum) seedlings and reduction of toxic effect of polyarene on plants after implementation of diatomite as a sorbent into contaminated soil are shown. A significant increase (by 2-3 times) of the plant growth in contaminated soil with the addition of diatomite has been revealed. The introduction of $2.5 \%$ diatomite into contaminated soil had the significant positive effect on barley seedlings.
\end{abstract}

\section{Introduction}

The impact of large amounts of pollutants changes the chemical and biological properties of soils and increases the phytotoxicity [1]. Soil phytotoxicity is an integral characteristic of soil biota and usually shows the dynamics of soil pollution. In this case, the plants are the most vulnerable biota component therefore it's a first link of the natural trophic chains absorbing various pollutants from soils [2-4]. The laboratory method is widespread method for determination of the soil phytotoxicity since it is the most effective, cheap, and relatively simple [5-7].

Benzo[a]pyrene (carcinogen and mutagen of the first hazard class) is one of the most dangerous chemical pollutants which maximum permissible concentration in soils is 20 $\mathrm{ng} / \mathrm{g}$ [8-12]. Its high toxicity and accumulation in the environment resulted in an increase of the number of studies of overall effect of the class of polycyclic aromatic hydrocarbons [13-15].

The use of mineral sorbents with unique physicochemical properties (high capacity, stable absorption ability, minimal catalytic effect on the cleaned media, sufficient strength, and hydrophobicity) is promising to reduce the negative impact of benzo[a]pyrene on soil and plants. One of such sorbents is diatomite which due to its properties and structure is able to adsorb benzo[a]pyrene reducing its availability for the plants and eliminating the negative effect of polyarene [16-18].

\footnotetext{
* Corresponding author: tolik.barakhov@mail.ru
} 
The goal of the study was to analyze the effect of various doses of diatomite on the

\section{Materials and Methods}

The experiment was performed as the phytotests using the following variations of samples: unpolluted soil without benzo[a]pyrene $(\mathrm{BaP})$ and mineral sorbent was used as a control, soil with various doses of diatomite, soil polluted with $\mathrm{BaP}$ in concentration $400 \mathrm{ng} / \mathrm{g}$, and polluted soil $\mathrm{BaP}$ in same concentration with diatomite. All experiments with carried out in triple replications. Diatomite was added into unpolluted and contaminated soil in doses of $0.5,1,2.5$, and $5 \%$ of the total volume (Fig. 1 ).

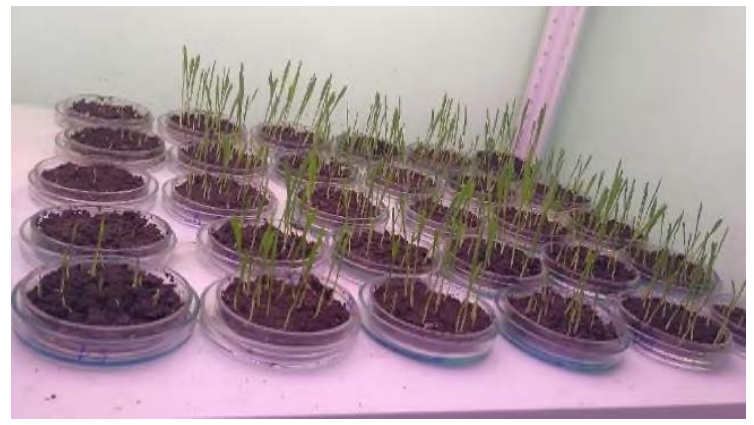

Fig. 1. Phytotesting of the soil.

Experimental soil was collected in strictly protected natural area the Persianovskaya Steppe Reserve and represented by ordinary chernozem containing $52 \%$ physical clay, $30 \%$ silt, and $0.4 \%$ of $\mathrm{CaCO}_{3}$, water extract $\mathrm{pH} 7.5$, and $33 \mathrm{cmol}(+) / \mathrm{kg}$ cation exchange capacity (CEC). The initially collected soil was cleaned from the plant remains and other inclusions, grinded in porcelain mortar and sifted through a sieve with $1-\mathrm{mm}$ holes. Soil aliquots $(50 \mathrm{~g})$ were placed in Petri plates and added with $\mathrm{BaP}$ solution in acetonitrile according to the experimental scheme. The samples were incubated over a week and supplied with diatomite as a mineral sorbent. Moistening of the samples was maintained at the $60 \%$ of water field capacity through all experimental period according Russian Standard GOST ISO 220302009. One week later after the adding of a sorbent, the soil was sown with germinated seeds of spring barley (Hordeum sativum distichum) Ratnik variety by 15 pieces per plate. The grown plants were harvested in 5 days after seeding and the root and stem length were measured according Russian Standard GOST 12038-84. The number of totally germinated seeds was calculated in 72 hours to determine the seed vigor according Russian Standard GOST 10968-88.

Evaluation of soil phytotoxicity was performed according to the formula [19]:

$$
\mathrm{THI}=\mathrm{T}_{\mathrm{fo}} / \mathrm{T}_{\mathrm{fc}}
$$

where THI is toxicity hazard index, $\mathrm{T}_{\mathrm{f} 0}$ is measured value of a parameter in experimental variant, and $\mathrm{T}_{\mathrm{fc}}$ is measured value of a parameter in control sample.

The toxicity hazard index was graded according to the following scale: toxicity class VI (stimulation) with THI $>1.10$, class $\mathrm{V}$ (normal) is equal to $0.91-1.10$, class IV (low toxicity) is equal to $0.71-0.90$, class III (medium toxicity) is $0.50-0.70$, class II (high toxicity) is $<0.50$, and class I (ultra high toxicity) mean that the environment is completely unfavorable for living of a test object.

The results were statistically processed using SigmaPlot v. 12.5 software and statistical significance of deviations was evaluated using Student's t-test at $\mathrm{p}<0.05$. 
The composition and texture characteristics of diatomite (Tables 26-28) were determined by X-ray fluorescence analysis (Spektroskan MAKS-GVM, Russia) and scanning electron microscopy (Carl Zeiss EVO-40 XVP, Germany).

\section{Results and Discussion}

According to scanning electron microscopy, it was found that dolomite is heterogenic in disperse and morphological structure (Fig. 2). Elementary composition of the dolomite sample is characterized by low content of heavy metals.
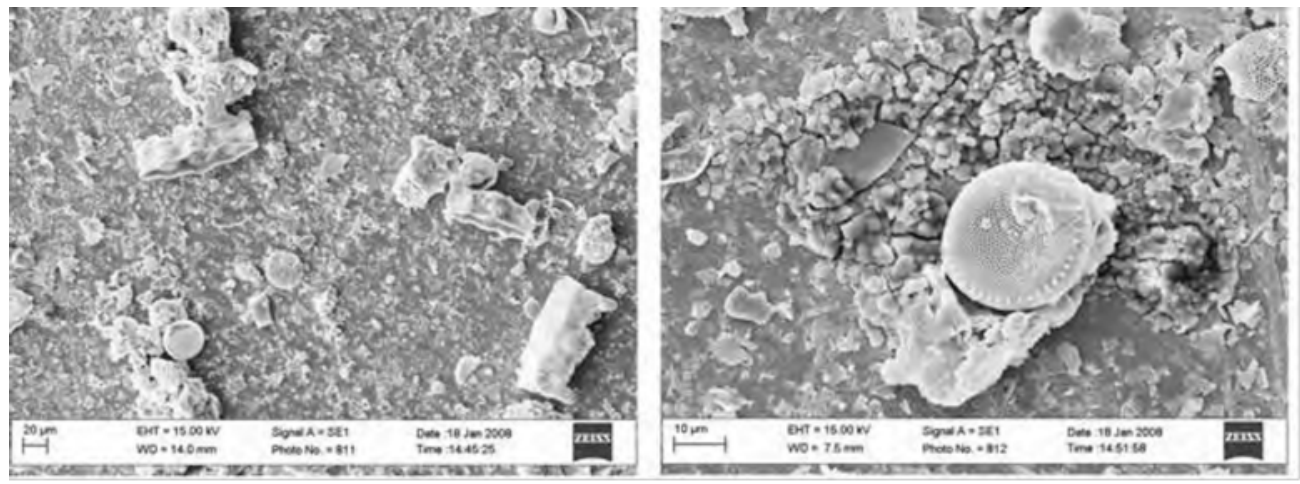

Fig. 2. Scanning electron microscopy of the diatomite surface.

It was found that the barley of the spring variety Ratnik used in the experiment is characterized by approximately $100 \%$ germination on ordinary chernozem that significantly decreased after the soil pollution with benzo[a]pyrene (Fig. 3).

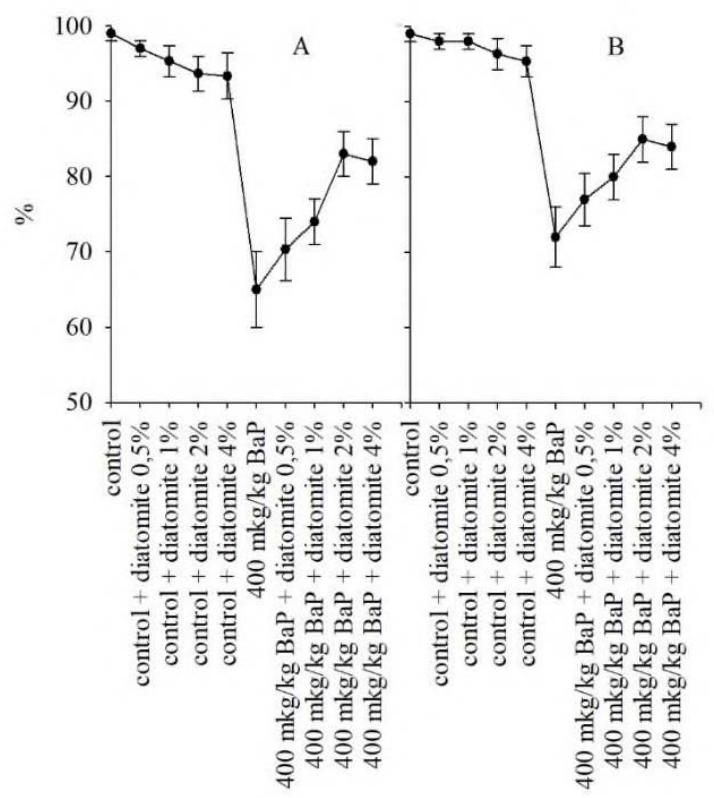

Fig. 3. Germination of spring barley. 
In addition, the barley seedlings affected by pollutant are distinguished with noticeable decrease in the height of the aboveground part and the root length (Fig. 4). The root length is more sensitive parameter to soil pollution. The addition of diatomite in $0.5,1$, and $2.5 \%$ doses is weakly affected the plant parameters. Insufficient decrease of the growth parameter of the plants was observed after addition of 5\% diatomite into initial soil that probably can be explained by sorption of nutrients by diatomite. The growth parameters and germination rate of the plants were significantly higher after addition of the sorbent into BaP polluted soil. There was strong positive effect on the plants observed along the rising of sorbent concentration in soil. However, the differences in the stimulating effect of 2.5 and $5 \%$ diatomite on plants were not significant therefore the addition of $2.5 \%$ diatomite into the soil heavily polluted with polyarene is environmentally reasonable and economically justified. This conclusion is confirmed by the assessment of the changes in the toxicity class of soil during remediation of polluted soils using diatomite.

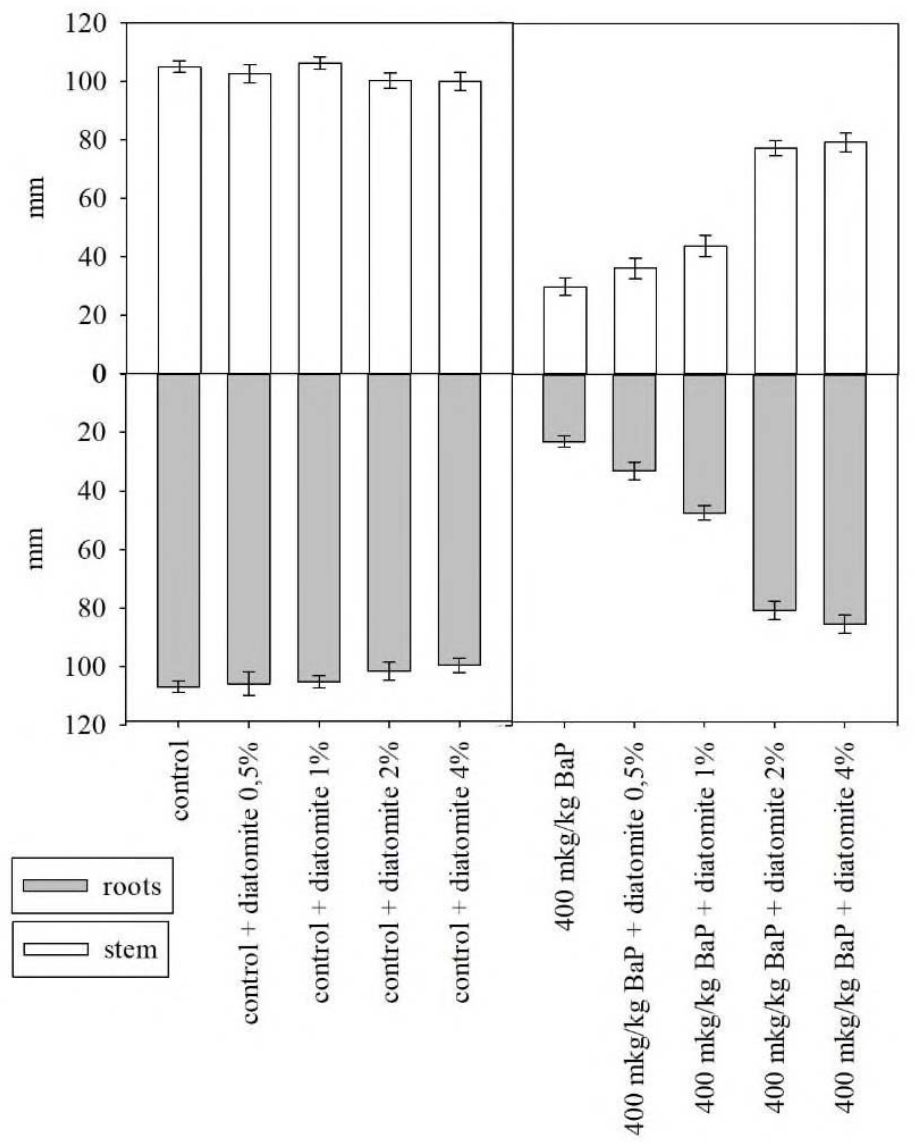

Fig. 4. Morphometric indicators of spring barley in the experiment.

Our calculations have shown (Table 1) that the addition of mineral sorbents into carbonaceous ordinary chernozem did not affect the soil toxicity class, but their use on polluted soil decreased the toxicity class. The best effect of diatomite was observed at 2.5 and $5 \%$ doses and environmental toxicity has shifted from class $\mathrm{V}$ (high toxicity) to class IV (low toxicity). 
Table 1. Class of toxicity of the soil.

\begin{tabular}{|c|c|c|c|c|c|c|}
\hline $\begin{array}{c}\text { Variants of the } \\
\text { experiment }\end{array}$ & $\begin{array}{c}\text { Root } \\
\text { length }\end{array}$ & $\begin{array}{c}\text { Stem } \\
\text { height }\end{array}$ & $\begin{array}{c}\text { Seed } \\
\text { germination }\end{array}$ & $\begin{array}{c}\text { Seed } \\
\text { germination } \\
\text { energy }\end{array}$ & $\begin{array}{c}\text { General } \\
\text { factor } \\
\text { toxicity } \\
\text { index }\end{array}$ & $\begin{array}{c}\text { Soil } \\
\text { hazard } \\
\text { class }\end{array}$ \\
\hline control & 1 & 1 & 1 & 1 & 1 & V \\
\hline $\begin{array}{c}\text { control + } \\
\text { diatomite } 0,5 \%\end{array}$ & 0.99 & 0.98 & 0.99 & 0.98 & 0.98 & V \\
\hline $\begin{array}{c}\text { control + } \\
\text { diatomite } 1 \%\end{array}$ & 0.98 & 1.01 & 0.99 & 0.97 & 0.99 & V \\
\hline $\begin{array}{c}\text { control + } \\
\text { diatomite } 2.5 \%\end{array}$ & 0.95 & 0.96 & 0.98 & 0.96 & 0.95 & V \\
\hline $\begin{array}{c}\text { control + } \\
\text { diatomite } 5 \%\end{array}$ & 0.93 & 0.95 & 0.97 & 0.95 & 0.95 & V \\
\hline $\begin{array}{c}400 \mathrm{mkg} / \mathrm{kg} \\
\mathrm{BaP}\end{array}$ & 0.21 & 0.29 & 0.73 & 0.66 & 0.47 & $\mathrm{II}$ \\
\hline $\begin{array}{c}400 \mathrm{mkg} / \mathrm{kg} \\
\mathrm{BaP}+\mathrm{diatomite} \\
0.5 \%\end{array}$ & 0.31 & 0.35 & 0.76 & 0.70 & 0.54 & $\mathrm{III}$ \\
\hline $\begin{array}{c}400 \mathrm{mkg} / \mathrm{kg} \\
\mathrm{BaP}+\mathrm{diatomite} \\
1 \%\end{array}$ & 0.44 & 0.42 & 0.81 & 0.75 & 0.60 & III \\
\hline $\begin{array}{c}400 \mathrm{mkg} / \mathrm{kg} \\
\mathrm{BaP}+\mathrm{diatomite} \\
2.5 \%\end{array}$ & 0.75 & 0.74 & 0.86 & 0.84 & 0.80 & IV \\
\hline $\begin{array}{c}400 \mathrm{mkg} / \mathrm{kg} \\
\mathrm{BaP}+\mathrm{diatomite} \\
5 \%\end{array}$ & 0.80 & 0.76 & 0.85 & 0.83 & 0.81 & $\mathrm{IV}$ \\
\hline
\end{tabular}

\section{Conclusions}

Thus, the positive effect of the diatomite treatment of soils polluted with benzo[a]pyrene on the growth of spring barley, germination rate, and seed vigor was found. The $2.5 \%$ diatomite has revealed a larger effect on polluted soil samples.

This study was supported by the Russian Foundation for Basic Research, project number 19-3490185 .

\section{References}

1. I.S. Belyuchenko, Nauchn. Zh. Kuban. Gos. Agrar. Univ. 95, 232-241 (2014).

2. S. Sushkova, T. Minkina, I. Deryabkina (Turina), E. Antonenko, S. Mandzhieva, I. Zamulina, T. Bauer, N. Gromakova, G. Vasilyeva, Polycyclic Aromatic Compounds, 39(5), 395-403 (2019). https://doi.org/ 10.1080/10406638.2017.1335217

3. J.H. Lee, Biotechnology and Bioprocess Engineering, 18(3), 431-439 (2013). DOI 10.1007/s12257-013-0193-8

4. D. Mani, C. Kumar International Journal of Environmental Science and Technology, 11(3), 843-872 (2014) https://doi.org/ 10.1007/s13762-013-0299-8G.

5. X. Jiang, L. Qiu, H. Zhao, Q. Song, H. Zhou, Q. Han, and X. Diao, Chemosphere 163, 125-132 (2016). https://doi.org/10.1016/j.chemosphere.2016.07.091 
6. E. V. Pribytkova, K. Y. Terentyev, Earth and Environmental Science, 263(1), 112-120 (2019). doi:10.1088/1755-1315/263/1/012020

7. V.V. Stolbova, D.V. Beregela, Moscow University soil science bulletin, 70(2), 71-77 (2015). https://doi.org/10.3103/S0147687415020088

8. X. Jiang, L. Qiu, H. Zhao, Q. Song, H. Zhou, Q. Han, and X. Diao, Chemosphere 163, 125-132 (2016). https://doi.org/10.1016/j.chemosphere.2016.07.091

9. M. Carvalho, M. Vila, F. Rohden, Eurasian Soil Science 4(2), 111-117 (2015).

10. K. Omidian., H. Rafiei, B. Bandy, Food and Chemical Toxicology 106, 165-180 (2017).https://doi.org/10.1016/j.fct.2017.05.037

11. P. W. Villalta, J. B. Hochalter, S. S. Hecht, Analytical chemistry, 89(23) 1237-1270 (2017) https://doi.org/10.1016/j.fct.2017.05.037

12. A. Tsibart, A. Gennadiev, Eurasian Soil Science 46(7), 728-741 (2013). doi:10.1134/S1064229313070090

13. N. Li, J. Qi, P. Wang, X. Zhang, T. Zhang, \& H. Li, Analytical Methods, 11(13), 18161821 (2019). https://doi.org/10.1039/C8AY02720J

14. A. Kamal, A. Cincinelli, T. Martellini, I. Palchetti, F. Bettazzi, \& R. N. Malik, International Journal of Environmental Health Research, 26(1), 37-57. https://doi.org/10.1080/09603123.2015.1007843

15. S. Sushkova, I. Deryabkina, E. Antonenko, R. Kizilkaya, V. Rajput, G. Vasilyeva, Science of the Total Environment, 633, 1386-1391 (2018). https://doi.org/10.1016/j.scitotenv.2018.03.287

16. P.W. Villalta, J.B. Hochalter, S.S. Hecht, Analytical chemistry, 89(23), 12735-12742 (2017). https://doi.org/10.1021/acs.analchem.7b02856

17. C. Wang, Z. Meng, P. Yao, L. Zhang, Z. Wang, Y. Lv, Y. Feng, Ecotoxicology and $\begin{array}{llll}\text { environmental safety, } & \mathbf{1 8 3}, & 109-121 & \text { (2019). }\end{array}$ https://doi.org/10.1016/j.ecoenv.2019.109552

18. S. Sushkova, T. Minkina, I. Deryabkina, S. Mandzhieva, I. Zamulina, T. Bauer, \& V. Rajput, Journal of Soils and Sediments, 18(6), 2368-2378 (2018).

19. C. Biache, S. Ouali, A. Cébron, C. Lorgeoux, S. Colombano, \& P. Faure, Journal of hazardous materials, 329, 1-10 (2017). https://doi.org/10.1016/j.jhazmat.2017.01.026 